\title{
PSYCHE.
}

\section{NOTES ON GLUPHISIA.}

\author{
BY HARRISON G. DYAR, NEW YORK CITY.
}

Dr. Packard has recorded his opinion concerning the species of Gluphisia in the August number of Psyche. From an examination of the same material, I have reached somewhat different conclusions, and it may not be without interest to compare the two views. The principal difference is in regard to G. wrightii. Dr. Packard considers it to be close to $G$. severa while I regard it as the $q$ of G. albofascia. I think that Dr. Packard has allowed himself to be led too closely by the statements of Henry Edwards, published with his original description. As in the case of Ichthyura bifiria, where Dr. Packard has simply copied Edwards's statement as to the relationship of that species, so here he repeats this course. I have shown that $I$. bifiria is not at all closely related to $I$. brucei as stated by Edwards, and, in the present case, G. wrightii, to my eye, bears no close relation to $G$. severa. I would certainly put it in the other section of the genus. The habitat is in accord with this arrangement, for the fauna of southern California is essentially that of the great arid region west of the Rockies (when the species are not endemic), while that of the Sierra Nevada is largely that of the Pacific
Northwest, and thus more similar to the Atlantic district.

Dr. Packard is inclined to consider G. albofascia and allies as "climatic varieties" of G. ridenda. As he does not define this term, I understand him to mean that they are modified to their present form by the direct influence of the climate of their habitat, and that if removed to some other region, they would not remain constant in their characters. That this is so cannot be assumed without proof, though the experiments of Weismann and others, to which Dr. Packard refers, might seem to indicate it.

I have not been able to perform any experiments in regard to these cases in Gluphisia; but I have done so in Ichthyura. There is a pale form of I. vau in the Rocky Mountain region, which bears much the same relation to $I$. vau that $G$. ridenda does to $G$. trilineata. Mr. C. A. Wiley had the kindness to send me eggs of this form from Miles City, Montana, and they were raised in the typically eastern climate of Boston; but produced an imago of the pale form.* I am inclined,

*The larvae had but four stages while $I$. vau from Boston have five, if my observations are correct. In the last case, I did not observe the stages in sequence, so that there is some chance of error. (See Can. ent., June and July 1892.$)$ 
therefore, to regard the climatic forms of Gluphisia as permanent, probably produced by the action of natural selection to fit them to their surroundings. I class them as local races, by which I mean that they are constant in their

Packard's Arrangement.

I. G. trilineata Pack. var. ridenda $\mathrm{Hy}$. Ed. rupta $\mathrm{Hy}$. Ed.

2. G. albofascia Hy. Ed. formosa $\mathrm{Hy}$. Ed.

3. G. wrightii Hy. Ed. severa $\mathrm{Hy}$. Ed. danbyi Neum. avimacula Huds. var. slossoniae Pack.

4. G. lintneri Grt. characters, but differ only slightly and in unessential particulars from the first described species.

I give below Dr. Packard's arrangement of Gluphisia and my own in parallel columns.

\section{Dyar's Arrangement.}

I. G. trilineata Pack. race ridenda $\mathrm{Hy}$. Ed. race quinquelinea Dyar.

2. G. albofascia Hy. Ed. wrightii $\mathrm{Hy}$. Edw. var. rupta $\mathrm{Hy}$. Ed.

3. G. formosa Hy. Ed.

4. G. severa Hy. Ed. var. danbyi Neum. race avimacula Huds. var. slossonii Pack.

5. G. lintneri Grt.

In tabular form, I separate the species as follows:-

Size small; no basal yellow dot (§ Gluphisia).

With a yellow (or black) central band on primaries.

Markings distinct . . . . . . . . trilineata.

Markings confused and irrorate . . . . . f formosa.

Pale, with no distinct yellowish markings . . . . albofascia.

Size large; a basal yellow dot on median vein (§ Eumelia).

A yellow angular discal dot . . . . . . . . severa.

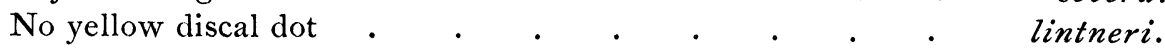

Nores.-On September I2th I caught, in Brookline, Mass., a large, battered Papilio cresphontes, which was flying rather feebly about some Salvias. It is the only one I have seen flying in Massachusetts.

At Nonquitt, Mass., Miss Ida M. Eliot and I had two larvae, Arctians unknown to us and certainly not acrea, of a cream-white color. The body was cream-white with three broken, blackish, longitudinal lines. There were no dark hairs. These larvae we fed on wild indigo-plant, Baptisia tinctoria, and after a few days the larger larva moulted, coming out of a deep, glossy, indigo-blue color, almost black. The smaller larva first moulted of a deep-blue gray color, then again of a deep blue like the other. These larvae grew to a length of nearly 3 inches, and were very striking in appearance.

Caroline G. Soule. 

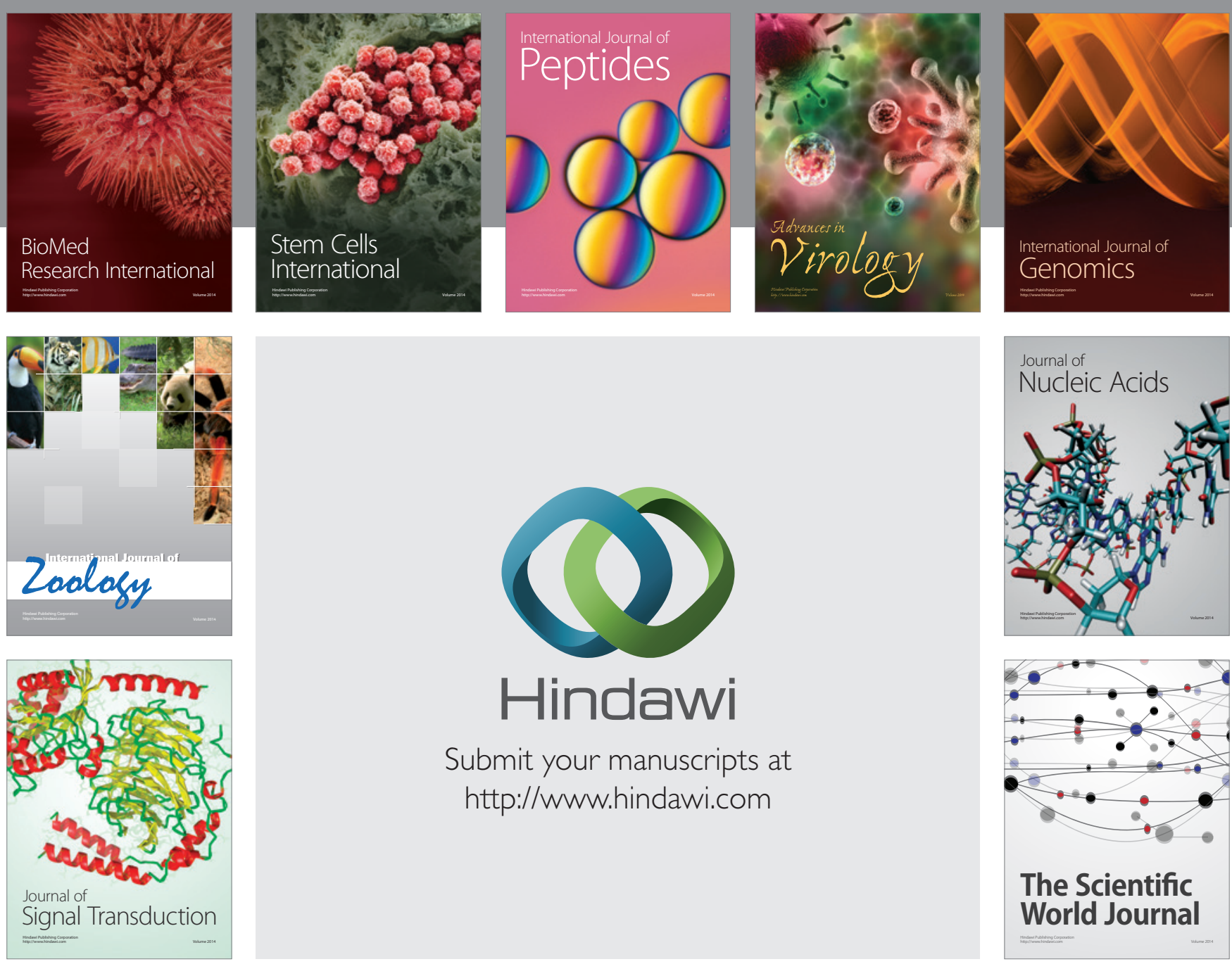

Submit your manuscripts at

http://www.hindawi.com
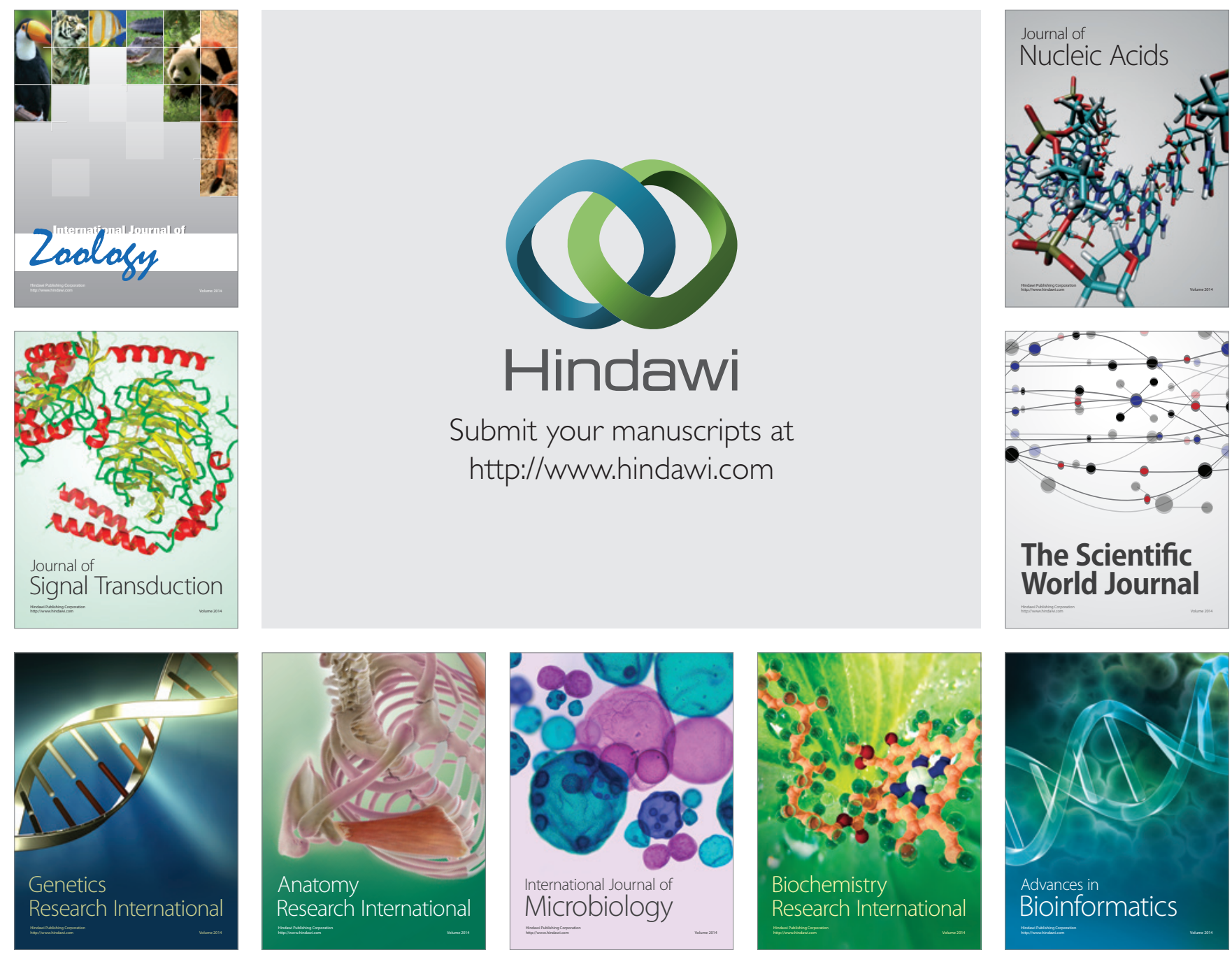

The Scientific World Journal
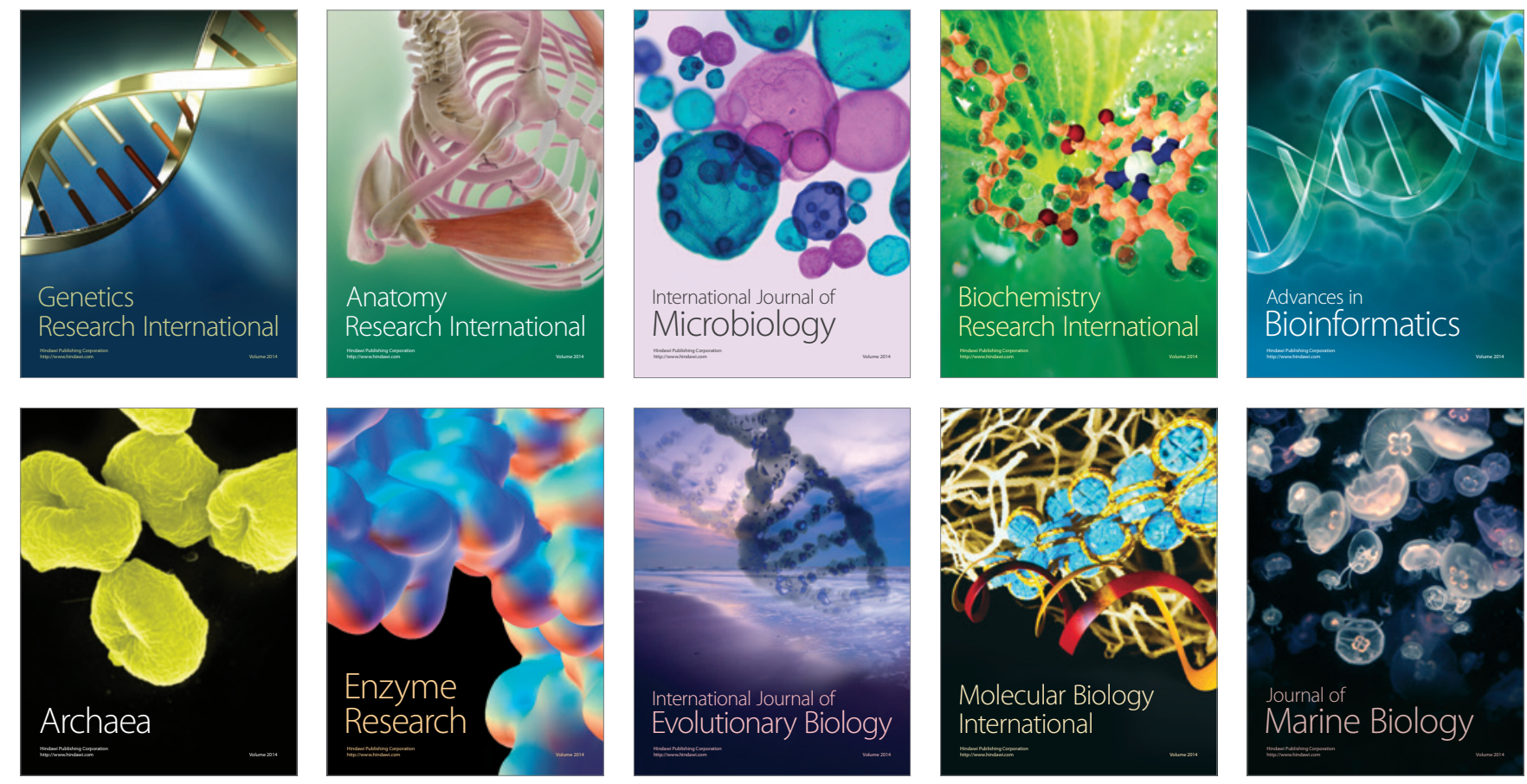